\title{
Metabolic Profile of Skimmianine in Rats Determined by Ultra-Performance Liquid Chromatography Coupled with Quadrupole Time-of-Flight Tandem Mass Spectrometry
}

\author{
Aihua Huang ${ }^{1,2}$, Hui Xu ${ }^{1, *}$, Ruoting Zhan ${ }^{1}$, Weiwen Chen ${ }^{1}$, Jiawei Liu ${ }^{1}$, Yuguang Chi ${ }^{2}$, \\ Daidi Chen ${ }^{2}$, Xiaoyu Ji ${ }^{1}$ and Chaoquan Luo ${ }^{1}$ \\ 1 Key Laboratory of Ministry of Education, Research Center of Chinese Herbal Resources and Engineering, \\ Guangzhou University of Chinese Medicine, Guangzhou 510006, China; hah2008@gzucm.edu.cn (A.H.); \\ zhanrt@gzucm.edu.cn (R.Z.); chenww@gzucm.edu.cn (W.C.); liujw@gzucm.edu.cn (J.L.); \\ jixy2017@163.com (X.J.); 18825146206@163.com (C.L.) \\ 2 School of Chinese Materia Medica, Guangzhou University of Chinese Medicine, Guangzhou 510006, China; \\ ygchi@gzucm.edu.cn (Y.C.); 13434325639@163.com (D.C.) \\ * Correspondence: zyfxsherry@gzucm.edu.cn; Tel./Fax: +86-20-3935-8331
}

Academic Editor: Marcello Iriti

Received: 25 January 2017; Accepted: 15 March 2017; Published: 23 March 2017

\begin{abstract}
Skimmianine is a furoquinoline alkaloid present mainly in the Rutaceae family. It has been reported to have analgesic, antispastic, sedative, anti-inflammatory, and other pharmacologic activities. Despite its critical pharmacological function, its metabolite profiling is still unclear. In this study, the in vivo metabolite profiling of skimmianine in rats was investigated using ultra-performance liquid chromatography coupled with quadrupole time-of-flight tandem mass spectrometry (UPLC/Q-TOF-MS). The metabolites were predicted using MetabolitePilot ${ }^{\mathrm{TM}}$ software. These predicted metabolites were further analyzed by $\mathrm{MS}^{2}$ spectra, and compared with the detailed fragmentation pathway of the skimmianine standard and literature data. A total of 16 metabolites were identified for the first time in rat plasma, urine, and feces samples after oral administration of skimmianine. Skimmianine underwent extensive Phase I and Phase II metabolism in rats. The Phase I biotransformations of skimmianine consist of epoxidation of olefin on its furan ring (M1) followed by the hydrolysis of the epoxide ring (M4), hydroxylation (M2, M3), O-demethylation (M5-M7), didemethylation (M14-M16). The Phase II biotransformations include glucuronide conjugation (M8-M10) and sulfate conjugation (M11-M13). The epoxidation of 2,3-olefinic bond followed by the hydrolysis of the epoxide ring and $O$-demethylation were the major metabolic pathways of skimmianine. The results provide key information for understanding the biotransformation processes of skimmianine and the related furoquinoline alkaloids.
\end{abstract}

Keywords: skimmianine; metabolites; UPLC/Q-TOF-MS; furoquinoline

\section{Introduction}

Skimmianine is a natural furoquinoline alkaloid widely present in plants of Rutaceae family, including Rutagravelens L. [1], Zanthoxylum nitidum [2], Zanthoxylum simulans Hance [3], and Dictamnus dasycarpus [4] etc. Skimmianine possesses non-narcotic analgesic [5], antispastic, sedative [3], antibacterial [6], antivirus [7], and other pharmacological activities, as well as antiplatelet aggregation [8]. It has been proposed to act as a potential treatment for Alzheimer's disease owing to its function of inhibiting acetylcholine esterase [2] and nitric oxide (NO) production [9]. Recently, skimmianine has been shown to exhibit an anti-inflammatory effect on ear and paw edema models. 
The mechanisms of its action included the suppression of TNF- $\alpha$ and IL-6 gene transcription, the inhibition of the production of NO, prostaglandin E2, and superoxide anions, as well as elastase-release $[1,10,11]$. Furthermore, skimmianine also exhibited cytotoxicity against a variety of cancer cell lines [12-15] and genotoxicity [16,17].

As is well known, drug metabolism is closely related to drug bioactivities and toxicity; therefore, identification of drug metabolites is of vital importance for elucidating drug pharmacological mechanisms and pharmacokinetic behavior. Limited information is known about the metabolism and pharmacokinetics of skimmianine in spite of our deep understanding of its pharmacological activities and toxicity. Available studies indicate that skimmianine has been distributed and eliminated rapidly after intravenous administration [18] and that it has been completely absorbed across intestinal epithelial cells [19]. No studies on the metabolites produced in vitro or in vivo have been reported. Nowadays, ultra-performance liquid chromatography coupled with quadrupole time-of-flight tandem mass spectrometry (UPLC/Q-TOF-MS) has become a valuable tool for drug metabolite identification due to its selectivity, sensitivity, and speediness [20]. In this paper, the method of UPLC/Q-TOF-MS was developed for the characterization of metabolic profiles in rat plasma, urine, and feces after oral administration of skimmianine. The results would provide an important basis for further pharmacological studies and biosafety evaluation.

\section{Results and Discussion}

\subsection{Mass Spectral Properities of Skimmianine}

To identify the metabolites of skimmianine in rats, the skimmianine standard was firstly analyzed by UPLC/Q-TOF-MS under the optimized conditions. The chromatogram and MS² spectra were recorded and the fragmentation pathways were proposed (Figure 1 and Figure S1).

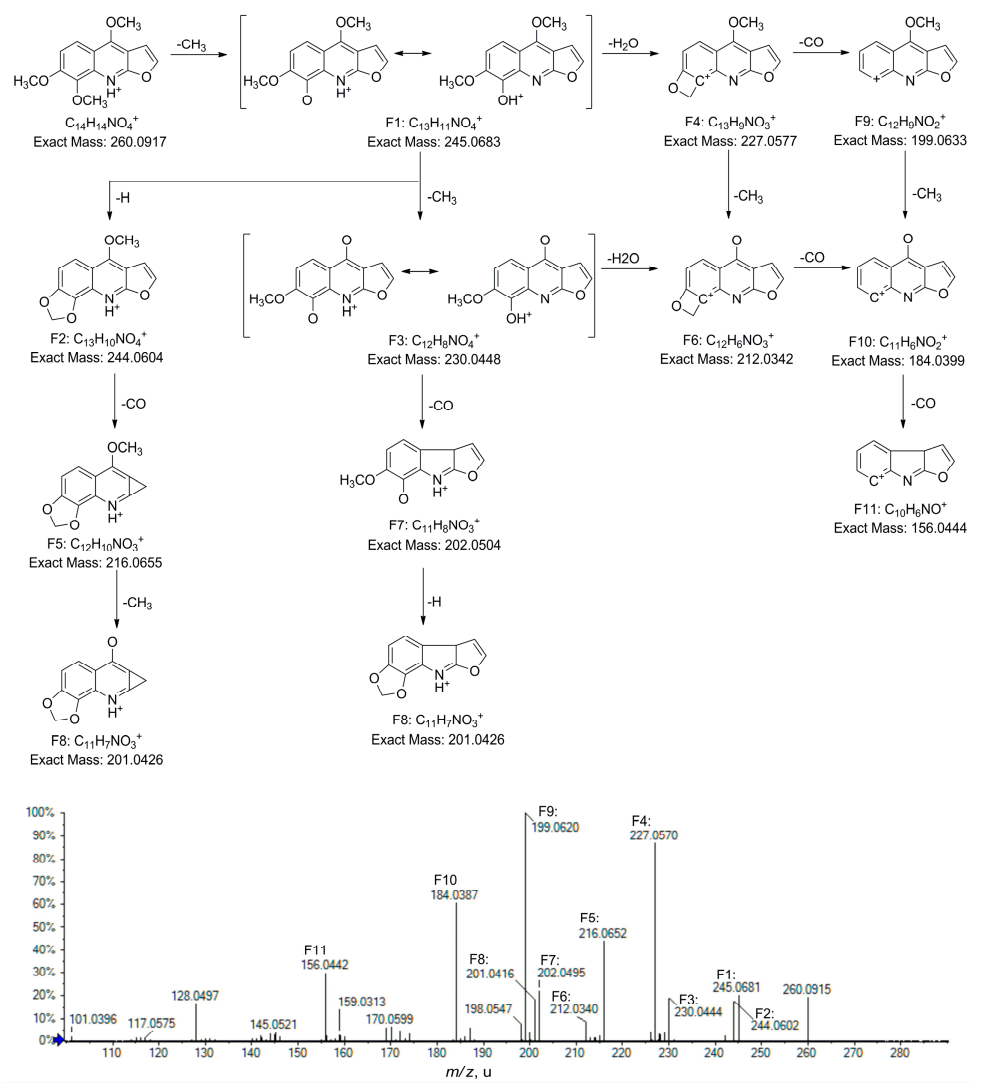

Figure 1. $\mathrm{MS}^{2}$ spectrum and the proposed fragmentation pathways of skimmianine standard. 
Skimmianine presented parent ion at $\mathrm{m} / z 260.0917\left(\mathrm{C}_{14} \mathrm{H}_{14} \mathrm{NO}_{4}{ }^{+}\right)$at $15.5 \mathrm{~min}$. The fragment ion at $m / z 245.0681\left(\mathrm{C}_{13} \mathrm{H}_{11} \mathrm{NO}_{4}{ }^{+}, \mathrm{F} 1\right)$ was attributed to the elimination of $\mathrm{CH}_{3}$. It may undergo an intramolecular proton transfer from $\mathrm{NH}^{+}$to $\mathrm{C} 8-\mathrm{OH}^{+}$. The subsequent loss of $\mathrm{H}_{2} \mathrm{O}$ of $\mathrm{F} 1$ resulted in a fragment ion at $\mathrm{m} / z 227.0575\left(\mathrm{C}_{13} \mathrm{H}_{9} \mathrm{NO}_{3}{ }^{+}, \mathrm{F} 4\right)$. The successive loss of $\mathrm{H}_{2} \mathrm{O}$ following $\mathrm{CH}_{3}$ might be a typical characteristic of skimmianine due to its vicinal methoxy groups at $\mathrm{C} 7$ and $\mathrm{C} 8$. F4 further fragmented in two ways, generating fragment ions at $m / z 199.0633\left(\mathrm{C}_{12} \mathrm{H}_{9} \mathrm{NO}_{2}{ }^{+}, \mathrm{F} 9\right), 212.0342$ $\left(\mathrm{C}_{12} \mathrm{H}_{6} \mathrm{NO}_{3}{ }^{+}, \mathrm{F} 6\right)$, and $184.0399\left(\mathrm{C}_{11} \mathrm{H}_{6} \mathrm{NO}_{2}{ }^{+}, \mathrm{F} 10\right)$. While the loss of $\mathrm{CH}_{3}$ following $\mathrm{CO}$ led to the formation of F9 and F10, F6 and F10 were produced vice versa. The ion at $m / z 156.0444\left(\mathrm{C}_{10} \mathrm{H}_{6} \mathrm{NO}^{+}\right.$, F11) was produced by the neutral loss of CO from F10. F4, F9, and F10 were the dominant peaks in the MS ${ }^{2}$ spectrum of skimmianine, implying that the successive elimination of $\mathrm{CH}_{3}$ and $\mathrm{H}_{2} \mathrm{O}$ must be the major fragmentation pathway. The minor peaks observed in the $\mathrm{MS}^{2}$ spectrum should be a result of other pathways. F1 might break up into the ions at $m / z 244.0602\left(\mathrm{C}_{13} \mathrm{H}_{10} \mathrm{NO}_{4}{ }^{+}, \mathrm{F} 2\right)$, $216.0652\left(\mathrm{C}_{12} \mathrm{H}_{10} \mathrm{NO}_{3}{ }^{+}, \mathrm{F} 5\right)$, and $201.0426\left(\mathrm{C}_{11} \mathrm{H}_{7} \mathrm{NO}_{3}{ }^{+}, \mathrm{F} 8\right)$ after the consecutive loss of $\mathrm{H}, \mathrm{CO}$, and $\mathrm{CH}_{3}$. Otherwise, $\mathrm{F} 1$ might undergo the successive elimination of $\mathrm{CH}_{3}, \mathrm{CO}$, and $\mathrm{H}$, producing the ions at $\mathrm{m} / z 230.0448\left(\mathrm{C}_{12} \mathrm{H}_{8} \mathrm{NO}_{4}{ }^{+}, \mathrm{F} 3\right), 202.0504\left(\mathrm{C}_{11} \mathrm{H}_{8} \mathrm{NO}_{3}{ }^{+}, \mathrm{F} 7\right)$, and $201.0426\left(\mathrm{C}_{11} \mathrm{H}_{7} \mathrm{NO}_{3}{ }^{+}, \mathrm{F} 8\right)$.

\subsection{Structure Elucidation of Skimmianine Metabolites}

After the oral administration of skimmianine to rats, plasma, urine, and feces samples were collected, extracted, and analyzed as described. The metabolites were predicted by using MetabolitePilot ${ }^{\mathrm{TM}}$ software and then confirmed manually based on the above fragmentation pathways of the skimmianine standard and the literature [21-23]. A total of 16 metabolites were identified in the biological samples originating from rats (Table 1). Extract ion chromatograms (EICs) of skimmianine and its metabolites are shown in Figure 2, and the related EICs in blank plasma, urine, and feces are shown in Figure S2 (see supplementary).

M1, M2, and M3 with protonated molecular weights of 276.0864, 276.0874, and 276.0861, respectively, were predicted to have the same molecular formula $\left(\mathrm{C}_{14} \mathrm{H}_{14} \mathrm{NO}_{5}{ }^{+}\right)$. These three metabolites harbored one additional $\mathrm{O}$ atom compared to skimmianine, indicating that they all resulted from an addition reaction of oxygen to skimmianine. M1 was eluted at $12.3 \mathrm{~min}$ and generated a fragment ion at $\mathrm{m} / z 248.0918\left(\mathrm{C}_{13} \mathrm{H}_{14} \mathrm{NO}_{4}{ }^{+}\right)$through the neutral loss of $\mathrm{CO}$ from the parent ion, suggesting that the $\mathrm{O}$ atom must be added to the $\mathrm{C} 2-\mathrm{C} 3$ double bond to form an epoxide. Subsequently, the fragment ions at $m / z 233.0679\left(\mathrm{C}_{12} \mathrm{H}_{11} \mathrm{NO}_{4}{ }^{+}\right), 232.0608\left(\mathrm{C}_{12} \mathrm{H}_{10} \mathrm{NO}_{4}{ }^{+}\right)$, and 204.0655 $\left(\mathrm{C}_{11} \mathrm{H}_{10} \mathrm{NO}_{3}{ }^{+}\right)$were produced via the continuous loss of $\mathrm{CH}_{3}, \mathrm{H}$, and $\mathrm{CO}$. The fragment ion at $\mathrm{m} / \mathrm{z}$ $233.0679\left(\mathrm{C}_{12} \mathrm{H}_{11} \mathrm{NO}_{4}{ }^{+}\right)$might have another fragmentation route, producing fragment ions at $\mathrm{m} / \mathrm{z}$ $205.0613\left(\mathrm{C}_{11} \mathrm{H}_{11} \mathrm{NO}_{3}{ }^{+}\right), 190.0834\left(\mathrm{C}_{10} \mathrm{H}_{8} \mathrm{NO}_{3}{ }^{+}\right), 175.0618\left(\mathrm{C}_{9} \mathrm{H}_{5} \mathrm{NO}_{3}{ }^{+}\right)$, and $147.0674\left(\mathrm{C}_{8} \mathrm{H}_{5} \mathrm{NO}_{2}{ }^{+}\right)$as a result of the consecutive loss of $\mathrm{CO}, \mathrm{CH}_{3}, \mathrm{CH}_{3}$, and $\mathrm{CO}$. The fragment ion at $m / z 162.0909\left(\mathrm{C}_{9} \mathrm{H}_{8} \mathrm{NO}_{2}{ }^{+}\right)$ was produced by the elimination of $\mathrm{CO}$ from the ion at $\mathrm{m} / z \mathrm{z} 190.0834\left(\mathrm{C}_{10} \mathrm{H}_{8} \mathrm{NO}_{3}{ }^{+}\right)$. From the ion at $\mathrm{m} / \mathrm{z}$ $248.0918\left(\mathrm{C}_{13} \mathrm{H}_{14} \mathrm{NO}_{4}{ }^{+}\right)$, another fragmentation route produced ions at $m / z 217.0735\left(\mathrm{C}_{12} \mathrm{H}_{11} \mathrm{NO}_{3}{ }^{+}\right)$, $216.0659\left(\mathrm{C}_{12} \mathrm{H}_{10} \mathrm{NO}_{3}{ }^{+}\right)$, and $188.0708\left(\mathrm{C}_{11} \mathrm{H}_{10} \mathrm{NO}_{2}{ }^{+}\right)$because of the consecutive loss of $\mathrm{CH}_{3} \mathrm{O}, \mathrm{H}$, and $\mathrm{CO}$. Based on the above fragmentation details, M1 was identified as a 2,3-epoxide metabolite of skimmianine.

$\mathrm{M} 2$ and $\mathrm{M} 3$ at retention times of 6.9 and $13.3 \mathrm{~min}$, respectively, yielded fragment ions at $\mathrm{m} / \mathrm{z}$ $261.0627\left(\mathrm{C}_{13} \mathrm{H}_{11} \mathrm{NO}_{5}{ }^{+}\right), 243.0527\left(\mathrm{C}_{13} \mathrm{H}_{9} \mathrm{NO}_{4}{ }^{+}\right), 215.0565\left(\mathrm{C}_{12} \mathrm{H}_{9} \mathrm{NO}_{3}{ }^{+}\right)$, and $200.0333\left(\mathrm{C}_{11} \mathrm{H}_{6} \mathrm{NO}_{3}{ }^{+}\right)$. These ions were all $16 \mathrm{u}$ more than those of skimmianine, suggesting that the fragmentation pathway was in complete accordance with that of the parent drug. M2 and M3 were thus identified as C5-hydroxylation and C6-hydroxylation metabolites of skimmianine, respectively.

M4 with $m / z 294.0972\left(\mathrm{C}_{14} \mathrm{H}_{16} \mathrm{NO}_{6}{ }^{+}\right)$was 34 u more than skimmianine, indicating that it was an oxidation and internal hydrolysis product of skimmianine. It produced fragment ions at $\mathrm{m} / \mathrm{z} 276.0862$ $\left(\mathrm{C}_{14} \mathrm{H}_{14} \mathrm{NO}_{5}^{+}\right), 248.0918\left(\mathrm{C}_{13} \mathrm{H}_{14} \mathrm{NO}_{4}^{+}\right), 217.0735\left(\mathrm{C}_{12} \mathrm{H}_{11} \mathrm{NO}_{3}{ }^{+}\right), 216.0659\left(\mathrm{C}_{12} \mathrm{H}_{10} \mathrm{NO}_{3}{ }^{+}\right), 188.0708$ $\left(\mathrm{C}_{11} \mathrm{H}_{10} \mathrm{NO}_{2}{ }^{+}\right)$, and $175.0618\left(\mathrm{C}_{9} \mathrm{H}_{5} \mathrm{NO}_{3}{ }^{+}\right)$. These ions were identical to those of M1. Therefore, M4 was identified as 2,3-epoxide hydrolysis product of M1. 
Table 1. MS data and identification results of skimmianine metabolites that appeared in rat plasma, urine, and feces.

\begin{tabular}{|c|c|c|c|c|c|c|c|}
\hline NO. & RT (min) & Mass Found & Error (ppm) & Formula $[\mathrm{M}+\mathrm{H}]^{+}$ & MS $^{2}$ Ions & Source & Metabolite Name \\
\hline M0 & 15.5 & 260.0919 & 0.7 & $\mathrm{C}_{14} \mathrm{H}_{14} \mathrm{NO}_{4}$ & $\begin{array}{c}245.0681,244.0602,227.0575,216.0652 \\
199.0633,184.0399\end{array}$ & P U F & Parent \\
\hline M1 & 12.3 & 276.0864 & -0.8 & $\mathrm{C}_{14} \mathrm{H}_{14} \mathrm{NO}_{5}$ & $\begin{array}{c}248.0918,233.0679,232.0608,217.0735 \\
216.0659,204.0655,188.0708\end{array}$ & P U & 2,3-epoxide of skimmianine \\
\hline M2 & 6.9 & 276.0874 & 2.7 & $\mathrm{C}_{14} \mathrm{H}_{14} \mathrm{NO}_{5}$ & $261.0627,243.0527,215.0565,200.0333$ & $\mathrm{U}$ & C5-hydroxylation of skimmianine \\
\hline M3 & 13.3 & 276.0861 & -2.0 & $\mathrm{C}_{14} \mathrm{H}_{14} \mathrm{NO}_{5}$ & $261.0627,243.0527,215.0565,200.0333$ & $\mathrm{U}$ & C6-hydroxylation of skimmianine \\
\hline M4 & 12.3 & 294.0976 & 1.2 & $\mathrm{C}_{14} \mathrm{H}_{16} \mathrm{NO}_{6}$ & $\begin{array}{c}276.0862,248.0918,217.0735,216.0659, \\
188.0708,175.0618\end{array}$ & P U F & 2,3-epoxide hydrolysis of M1 \\
\hline M5 & 9.9 & 246.0763 & 0.8 & $\mathrm{C}_{13} \mathrm{H}_{12} \mathrm{NO}_{4}$ & $231.0531,213.0419,185.0470$ & PUF & C4-O-demethylation of skimmianine \\
\hline M6 & 11.7 & 246.0761 & 0 & $\mathrm{C}_{13} \mathrm{H}_{12} \mathrm{NO}_{4}$ & $231.0526,216.0289,188.0342,160.0388$ & P U & C8-O-demethylation of skimmianine \\
\hline M7 & 13.1 & 246.0760 & -0.2 & $\mathrm{C}_{13} \mathrm{H}_{12} \mathrm{NO}_{4}$ & $231.0511,216.0274,188.0327,160.0384$ & P U F & C7-O-demethylation of skimmianine \\
\hline M8 & 7.7 & 422.1079 & -0.6 & $\mathrm{C}_{19} \mathrm{H}_{20} \mathrm{NO}_{10}$ & $246.0759,231.0525,213.0425,185.0471$ & P U & Glucuronidation of M5 \\
\hline M9 & 8.9 & 422.1076 & -1.3 & $\mathrm{C}_{19} \mathrm{H}_{20} \mathrm{NO}_{10}$ & $246.0759,231.0525,216.0289,188.0339$ & PU & Glucuronidation of M6 \\
\hline M10 & 11.3 & 422.1087 & 1.3 & $\mathrm{C}_{19} \mathrm{H}_{20} \mathrm{NO}_{10}$ & $246.0760,231.0530,216.0297$ & PU & Glucuronidation of M7 \\
\hline M11 & 11.7 & 326.0332 & 0.9 & $\mathrm{C}_{13} \mathrm{H}_{12} \mathrm{NO}_{7} \mathrm{~S}$ & $246.0759,231.0525,216.0289,188.0339$ & PU & Sulfation of M6 \\
\hline M12 & 14.4 & 326.0335 & 1.9 & $\mathrm{C}_{13} \mathrm{H}_{12} \mathrm{NO}_{7} \mathrm{~S}$ & $246.0759,231.0525,216.0289,188.0339$ & PU & Sulfation of M7 \\
\hline M13 & 12.0 & 356.0438 & 1.0 & $\mathrm{C}_{14} \mathrm{H}_{14} \mathrm{NO}_{8} \mathrm{~S}$ & $276.0866,261.0622,243.0527,200.0344$ & P U & Sulfation of M3 \\
\hline M14 & 6.1 & 232.0604 & -0.4 & $\mathrm{C}_{12} \mathrm{H}_{10} \mathrm{NO}_{4}$ & $217.0370,189.0420,161.0473$ & P U F & $\begin{array}{l}\text { C4, C8-O-Didemethylation } \\
\text { of skimmianine }\end{array}$ \\
\hline M15 & 8.5 & 232.0601 & -1.5 & $\mathrm{C}_{12} \mathrm{H}_{10} \mathrm{NO}_{4}$ & $217.0369,189.0404,161.0476$ & $\mathrm{U}$ & $\begin{array}{l}\text { C4, C7-O-Didemethylation } \\
\text { of skimmianine }\end{array}$ \\
\hline M16 & 14.9 & 232.0603 & -0.7 & $\mathrm{C}_{12} \mathrm{H}_{10} \mathrm{NO}_{4}$ & $217.0371,189.0427,161.0468$ & P U & $\begin{array}{l}\text { C7, C8-O-Didemethylation } \\
\text { of skimmianine }\end{array}$ \\
\hline
\end{tabular}

P: plasma; U: urine; F: feces. 

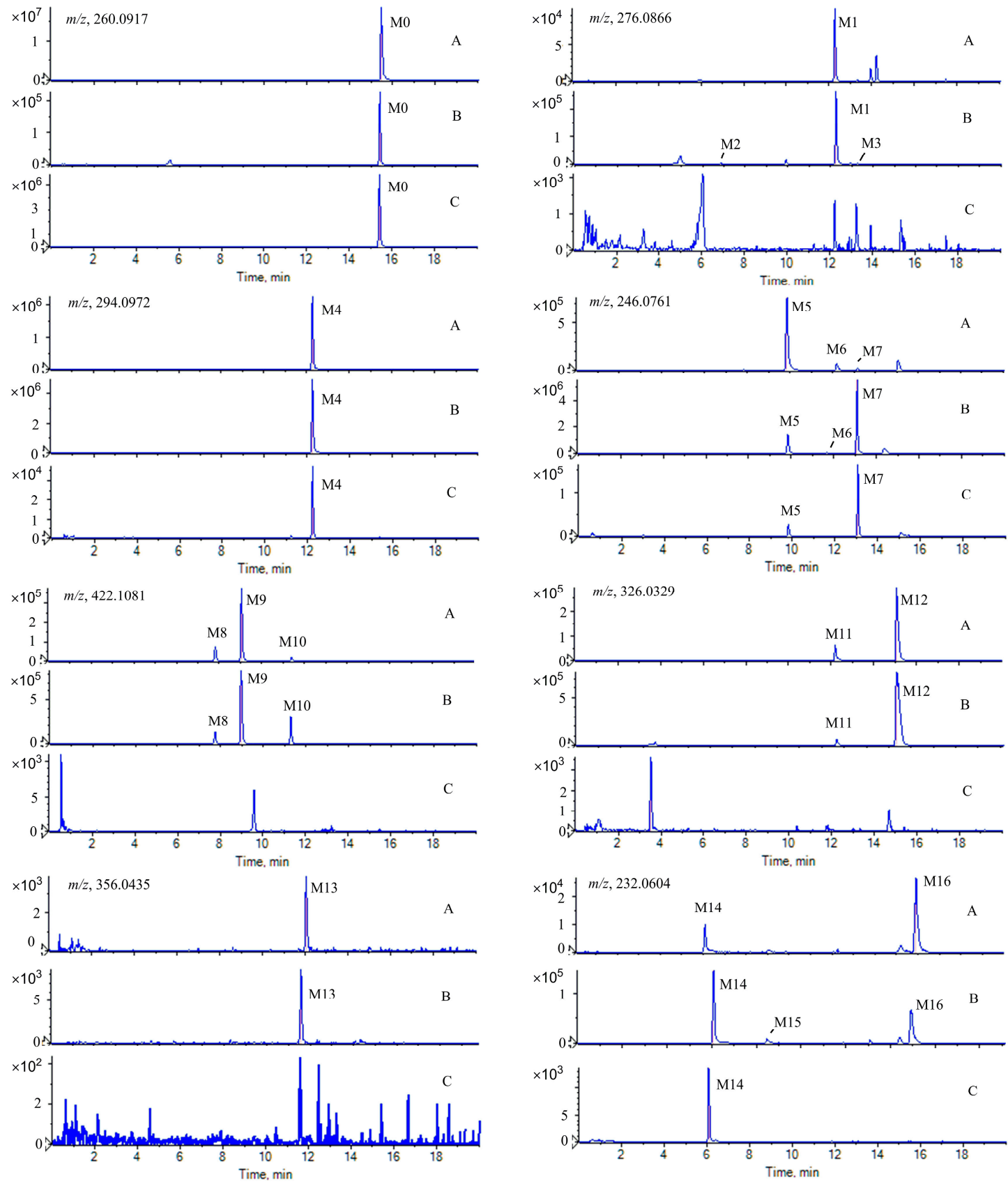

Figure 2. Extracted ion chromatograms of skimmianine and its metabolites in rats: A, plasma samples; $\mathrm{B}$, urine samples; $\mathrm{C}$, feces samples.

M5, M6, and M7 at rentention times of 9.9, 11.7, and $13.1 \mathrm{~min}$ shared the same formula $\left(\mathrm{C}_{13} \mathrm{H}_{12} \mathrm{NO}_{4}^{+}\right)$. These metabolites lost one $\mathrm{C}$ and two $\mathrm{H}$ atoms from skimmianine, indicating that these metabolites were demethylation products of skimmianine. M5 along with its fragment ions at $\mathrm{m} / z 231.0531\left(\mathrm{C}_{12} \mathrm{H}_{9} \mathrm{NO}_{4}{ }^{+}\right), 213.0419\left(\mathrm{C}_{12} \mathrm{H}_{7} \mathrm{NO}_{3}{ }^{+}\right)$, and $185.0470\left(\mathrm{C}_{11} \mathrm{H}_{7} \mathrm{NO}_{2}{ }^{+}\right)$were all $14 \mathrm{u}$ less than those of skimmianine. The fragmentation pattern was consistent with that of the parent molecule. M5 was thus identified as C4-O-demethylation product of skimmianine. In the case of M6 and $\mathrm{M} 7$, the fragmentation pattern was different from that of skimmianine due to the lack of vicinal methoxy groups at $\mathrm{C} 7$ and $\mathrm{C} 8$. The fragment ions at $m / z 231.0526\left(\mathrm{C}_{12} \mathrm{H}_{9} \mathrm{NO}_{4}{ }^{+}\right), 216.0289\left(\mathrm{C}_{11} \mathrm{H}_{6} \mathrm{NO}_{4}{ }^{+}\right)$, $188.0327\left(\mathrm{C}_{10} \mathrm{H}_{6} \mathrm{NO}_{3}{ }^{+}\right)$, and $160.0384\left(\mathrm{C}_{9} \mathrm{H}_{6} \mathrm{NO}_{2}{ }^{+}\right)$were produced owing to the consecutive loss of 
$\mathrm{CH}_{3}, \mathrm{CH}_{3}, \mathrm{CO}$, and $\mathrm{CO}$. Because $\mathrm{C} 7-\mathrm{OH}$ is less polar than $\mathrm{C} 8-\mathrm{OH}, \mathrm{M} 6$ and $\mathrm{M} 7$ were identified as $\mathrm{C} 8-\mathrm{O}-$ demethylation and $\mathrm{C} 7-\mathrm{O}$-demethylation products of skimmianine, respectively.

Eluted at 7.7, 8.9, and $11.3 \mathrm{~min}$, respectively, M8, M9, and M10 were deduced to have the same formula $\left(\mathrm{C}_{19} \mathrm{H}_{20} \mathrm{NO}_{10}{ }^{+}\right)$. All these metabolites displayed a neutral loss of $176 \mathrm{u}$, suggesting that they were demethylated and glucuronidated products of skimmianine. M8 yielded fragment ions at $\mathrm{m} / \mathrm{z}$ $246.0759\left(\mathrm{C}_{13} \mathrm{H}_{12} \mathrm{NO}_{4}{ }^{+}\right), 231.0525\left(\mathrm{C}_{12} \mathrm{H}_{9} \mathrm{NO}_{4}{ }^{+}\right), 213.0425\left(\mathrm{C}_{12} \mathrm{H}_{7} \mathrm{NO}_{3}{ }^{+}\right)$, and $185.0471\left(\mathrm{C}_{11} \mathrm{H}_{7} \mathrm{NO}_{2}{ }^{+}\right)$ via the sequential loss of $\mathrm{C}_{6} \mathrm{H}_{8} \mathrm{O}_{6}, \mathrm{CH}_{3}, \mathrm{H}_{2} \mathrm{O}$, and $\mathrm{CO}$. The dominant fragment ions were similar to those of M5. M8 was identified as a glucuronidated product of M5. Both M9 and M10 yielded fragment ions at $m / z 246.0759\left(\mathrm{C}_{13} \mathrm{H}_{12} \mathrm{NO}_{4}{ }^{+}\right), 231.0525\left(\mathrm{C}_{12} \mathrm{H}_{9} \mathrm{NO}_{4}{ }^{+}\right), 216.0289\left(\mathrm{C}_{11} \mathrm{H}_{6} \mathrm{NO}_{4}{ }^{+}\right)$, and $188.0339\left(\mathrm{C}_{10} \mathrm{H}_{6} \mathrm{NO}_{3}{ }^{+}\right)$. The fragmentation pattern was consistent with that of $\mathrm{M} 6$ and M7. As the polarity of M9 is larger than that of M10, M9 and M10 were assigned to glucuronidated products of M6 and M7, respectively.

M11 and M12 had the same formula $\left(\mathrm{C}_{13} \mathrm{H}_{12} \mathrm{NO}_{7} \mathrm{~S}^{+}\right)$, and these two metabolites were eluted at 11.7 and $14.4 \mathrm{~min}$, respectively. Both metabolites displayed a neutral loss of $80 \mathrm{u}$, suggesting that they were demethylated and sulfated products of skimmianine. M11 and M12 also yielded fragment ions at $m / z 246.0759\left(\mathrm{C}_{13} \mathrm{H}_{12} \mathrm{NO}_{4}^{+}\right), 231.0525\left(\mathrm{C}_{12} \mathrm{H}_{9} \mathrm{NO}_{4}{ }^{+}\right), 216.0289\left(\mathrm{C}_{11} \mathrm{H}_{6} \mathrm{NO}_{4}{ }^{+}\right)$, and $188.0339\left(\mathrm{C}_{10} \mathrm{H}_{6} \mathrm{NO}_{3}{ }^{+}\right)$. This was also consistent with that of M6 and M7. M11 and M12 were identified as sulfated products of M6 and M7, respectively.

M13 displayed a protonated molecular ion at $m / z 356.0435\left(\mathrm{C}_{14} \mathrm{H}_{14} \mathrm{NO}_{8} \mathrm{~S}^{+}\right)$at retention time $12.0 \mathrm{~min}$. It further yielded a fragment ion at $m / z 276.0866\left(\mathrm{C}_{14} \mathrm{H}_{14} \mathrm{NO}_{5}{ }^{+}\right)$via a neutral loss of $80 \mathrm{u}$, suggesting that M13 was an oxygenated and sulfated product of skimmianine. The fragment ions were similar to those of M2 and M3. Moreover, considering the elution time of these metabolites, M13 was identified as the sulfated product of M3.

M14, M15, and M16 were eluted at 6.1, 8.5, and 14.9 min, respectively. They were supposed to share the same molecular formula $\left(\mathrm{C}_{12} \mathrm{H}_{10} \mathrm{NO}_{4}{ }^{+}\right), \mathrm{C}_{2} \mathrm{H}_{4}$ less than the parent molecule. All of these metabolites generated fragment ions at $m / z 217.0371\left(\mathrm{C}_{11} \mathrm{H}_{7} \mathrm{NO}_{4}{ }^{+}\right), 189.0427\left(\mathrm{C}_{10} \mathrm{H}_{7} \mathrm{NO}_{3}{ }^{+}\right)$, $161.0468\left(\mathrm{C}_{9} \mathrm{H}_{7} \mathrm{NO}_{2}{ }^{+}\right)$, and $133.0522\left(\mathrm{C}_{8} \mathrm{H}_{7} \mathrm{NO}^{+}\right)$via the continuous loss of $\mathrm{CH}_{3}, \mathrm{CO}, \mathrm{CO}$, and $\mathrm{CO}$. According to the polarity of molecules, they were speculated as $\mathrm{C} 4, \mathrm{C} 8$-O-didemethylation; $\mathrm{C} 4, \mathrm{C} 7-\mathrm{O}$-didemethylation and $\mathrm{C}$, C8-O-didemethylation products of skimmianine.

Figure 3 showed $\mathrm{MS}^{1}$ and $\mathrm{MS}^{2}$ spectra of the parent drug and its metabolites identified in rat urine samples. The mass spectra of metabolites in plasma and feces were listed in Figures S3 and S4. The proposed chemical structures and metabolic pathways of skimmianine metabolites are summarized in Figure 4. Since all metabolites were identified using high-resolution mass spectrometry, further studies are needed to confirm their structures and configurations. 

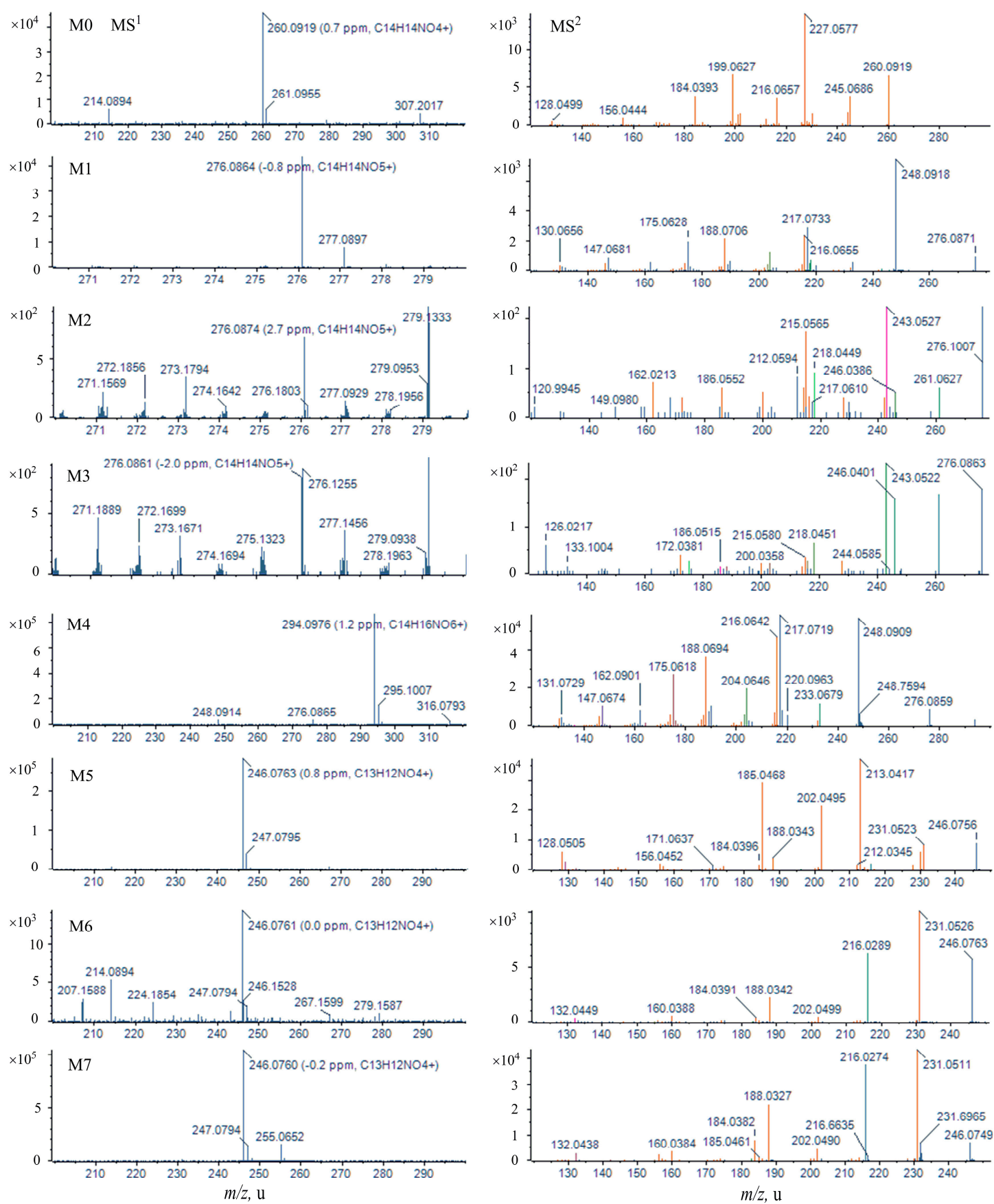

Figure 3. Cont. 

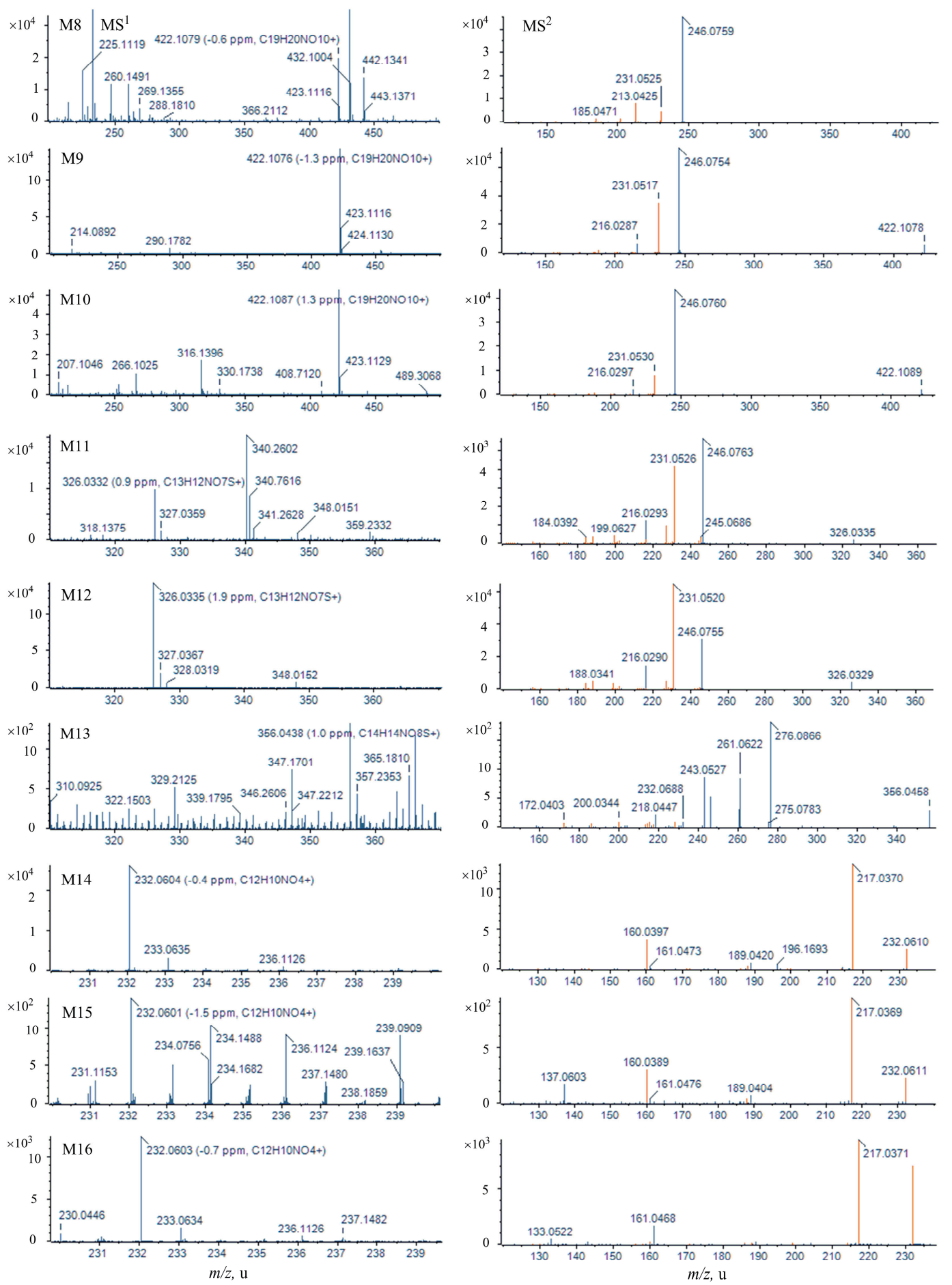

Figure 3. $\mathrm{MS}^{1}$ and $\mathrm{MS}^{2}$ spectra of the parent drug and its metabolites identified in rat urine sample. 


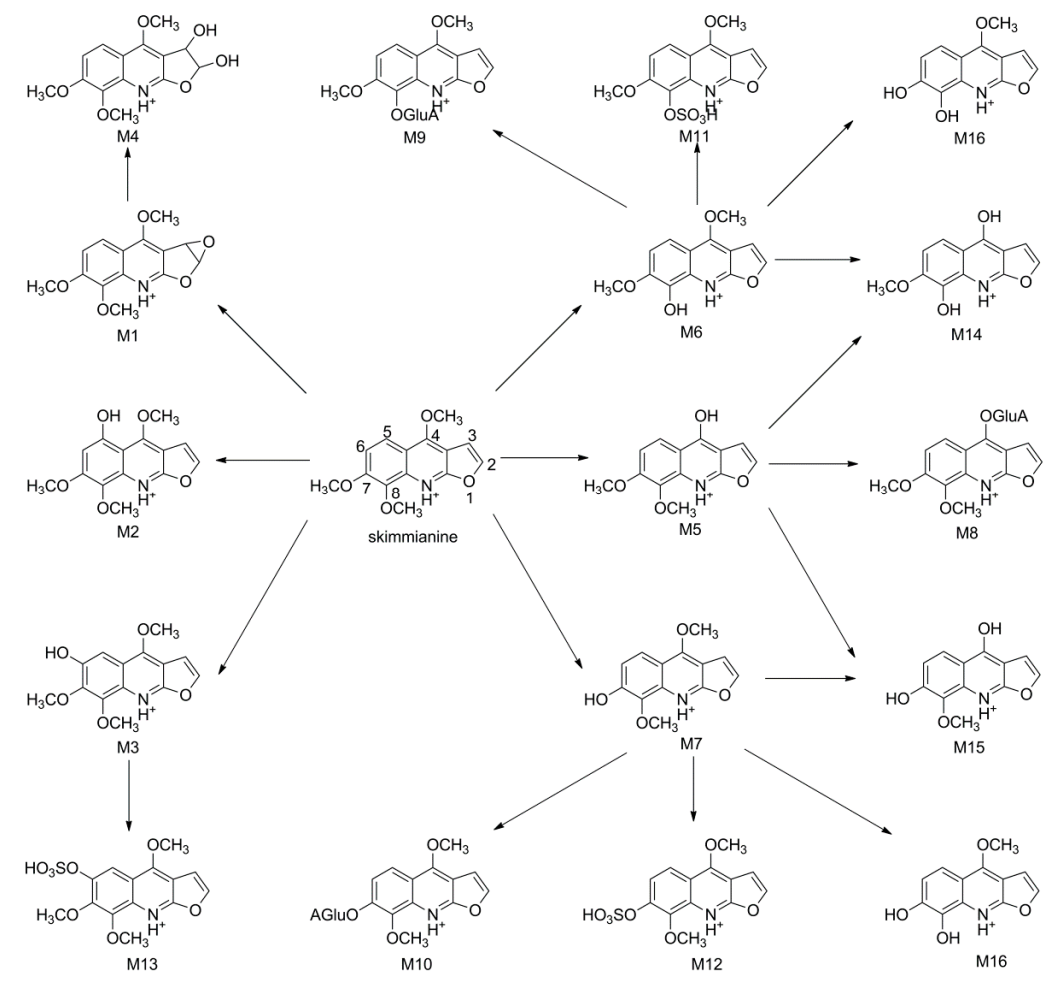

Figure 4. Proposed metabolic pathways of skimmianine in rats.

\subsection{Metabolic Profile of Skimmianinein Rats}

Skimmianine was administered to rats orally and the structures of its 16 metabolites were identified. The metabolites included 10 Phase I compounds (M1-7, M14-16) and 6 Phase II ones (M8-13). The Phase I metabolism was composed of O-demethylation, didemethylation, hydroxylation, and epoxidation of olefin on the furan ring of skimmianine and followed by the hydrolysis of its epoxide ring. The Phase II metabolism included glucuronidation and sulfation of some Phase I metabolites. The Phase I metabolic pathways were similar to those of dictamnine, which was also a furoquinoline alkaloid [21-23]. It seemed that the epoxidation of 2,3-olefinic on the furan ring followed by the hydrolysis of its epoxide ring was a typical characteristic of the furoquinoline alkaloid metabolism. Besides that, $\mathrm{O}$-demethylation of the methoxy group must also be a major pattern in the Phase I metabolism. In comparison, metabolites resulting from the oxidation of the benzene moiety were merely detectable. The major pathway of the Phase II metabolism was glucuronidation and sulfation after $O$-demethylation.

As shown in Figure 2, the distribution of the metabolites was tissue-specific. While all 16 (Figure 3) metabolites were found in rat urine, 13 (Figure S3) and 4 (Figure S4) metabolites were detected in plasma and feces, respectively. Four metabolites (M4, M5, M7, and M14) were common in the rat plasma, urine, and feces (Figure 2). M4 was observed as the most abundant metabolite of skimmianine in plasma and urine. Comparing the metabolic profile in urine with that in plasma, the level of skimmianine was observed to have decreased dramatically, suggesting that skimmianine was widely metabolized in rats and excreted mainly through urine in the form of metabolites.

Various biological activities and genotoxicity of skimmianine might correlate with its strong metabolism. It has been reported that 8-hydroxydictamnine, a hydroxylation product of dictaminine, showed strong mutagenicity with liver extracts of Wistar rats injected with phenobarbital, but 7-hydroxydictamnine and other furoquinolines with a hydroxy group at C7 were inactive in the Salmonella typhimurium strain TA98 [23]. In this study, M6 possessed a hydroxy group at C8 and was observed in plasma and urine. Whether M6 is related to mutagenicity needs to be determined 
with further investigation. An assessment of the contribution to the overall activity or toxicity from key metabolites would be interesting.

\section{Materials and Methods}

\subsection{Chemical, Reagents, and Materials}

Skimmianine (No. 160106, purity 98.0\%) was purchased from Shanghai Yuan-Mu Bio-Technology Ltd. Co., (Shanghai, China). Acetonitrile and formic acid of HPLC grade agents were purchased from Merck (Darmstadt, Germany). All other agents were of analytical grade and obtained from Guangzhou Chemical Reagent Factory (Guangzhou, China). Purified water was prepared from a Milli-Q system (Millipore Billerica, MA, USA). The HyperSep $\mathrm{C}_{18}$ solid-phase extraction (SPE) column (1000 mg, $6 \mathrm{~mL}$ ) was purchased from Thermo Electron Corporation (Waltham, MA, USA).

\subsection{Instrumentation and Analytical Conditions}

Chromatographic separation was performed on a Shimadzu Nexera UHPLC LC-30A system (Shimadzu Corporation, Tokyo, Japan) with an ODS column (Shimadzu, $2.0 \mathrm{~mm}$ i.d. $\times 100 \mathrm{~mm}$ ) at $35{ }^{\circ} \mathrm{C}$. The mobile phase, consisting of Solvent A $(0.1 \%$ formic acid solution) and Solvent B ( $0.1 \%$ formic acid acetonitrile), was delivered at a flow rate of $0.4 \mathrm{~mL} / \mathrm{min}$ using a gradient program as follows: $0-10 \mathrm{~min}, 5 \%-20 \%$ B; $10-15 \mathrm{~min}, 20 \%-35 \% \mathrm{~B} ; 15-20 \mathrm{~min}, 35 \%-100 \%$ B. Each injection volume was $3 \mu \mathrm{L}$.

MS data were acquired on an AB SCIEX Triple TOF 5600 (AB Sciex Pte. Ltd., Singapore). The system was controlled with AB SCIEX Analyst TF (Version 1.7) software (AB Sciex Pte. Ltd., Singapore, Singapore). Information-dependent acquisition (IDA) and mass defect filter information-dependent acquisition (MDF-IDA) were used for identifying metabolites. Mass spectrometric conditions were as follows: interface, positive electrospray ionization (ESI); gas 1 and 2, nitrogen 50 psi; curtain gas, nitrogen $40 \mathrm{psi}$; source temperature $500{ }^{\circ} \mathrm{C}$; ion spray voltage $5500 \mathrm{~V}$; declustering potential $100 \mathrm{~V}$, scan range $100-800 \mathrm{Da}$, and collision energy $10 \mathrm{eV}$.

\subsection{Animals, Dosage and Biological Sample Collection}

Male Sprague-Dawley rats $(250 \pm 20 \mathrm{~g})$ used in this study were provided by the Experimental Animal Center of Guangzhou University of Chinese Medicine. The laboratory animal license number is SCXK 2013-0020. These animals were maintained in an air-conditioned animal facility at $23 \pm 2{ }^{\circ} \mathrm{C}$, with a humidity of $55 \% \pm 5 \%$ and a $12 \mathrm{~h}$ light/dark cycle for 5 days before use. The rats had free access to water and a standard diet. Animal welfare and experimental procedures were strictly in accordance with the guidelines of the Committee on the Care and Use of Laboratory Animals in China and the related ethical regulations of Guangzhou University of Chinese Medicine.

The rats were randomly divided into 3 groups, with A for the blank control group, B for plasma collection group, and $\mathrm{C}$ for the urine and feces collection group, 6 rats per group. Before administration, the rats were fasted for $12 \mathrm{~h}$ but were allowed water access ad libitum. Skimmianine suspension in a $0.5 \%$ carboxymethyl cellulose sodium aqueous solution was orally administered to Groups B and C at a dose of $20 \mathrm{mg} \cdot \mathrm{kg}^{-1}$ body weight, while a $0.5 \%$ carboxymethyl cellulose sodium aqueous solution was orally administered to Group A.

The rats of Group B were anesthetized at $0.5 \mathrm{~h}, 1 \mathrm{~h}, 2 \mathrm{~h}, 3 \mathrm{~h}, 4 \mathrm{~h}$, and $6 \mathrm{~h}$ after doses, respectively. The blood samples were collected from aorta abdominalis in heparinized tubes. All blood samples were then centrifuged at $1274 \times \mathrm{g}$ for $15 \mathrm{~min}$ at $4{ }^{\circ} \mathrm{C}$ and mixed together to produce the pooled plasma. Blank plasma samples collected from Group A were prepared following the same procedures.

For the collection of urine and feces samples after dose, the rats of Group $\mathrm{C}$ were put into metabolic cages individually. The samples were collected at $24 \mathrm{~h}$ post-intake, respectively, while control urine and feces samples were collected before drug administration. All samples were stored at $-80^{\circ} \mathrm{C}$. The frozen urine and feces samples were thawed at room temperature before use. 


\subsection{Biological Sample Preparation}

Two milliliters of plasma sample were loaded onto a pretreated solid-phase extraction (SPE) column. The column was washed with $6 \mathrm{~mL}$ of water, followed by elution using $6 \mathrm{~mL}$ of methanol. The methanol eluate was evaporated to dryness at $35^{\circ} \mathrm{C}$. The residue was reconstituted in $300 \mu \mathrm{L}$ of acetonitrile and water (50:50, $v / v)$ and centrifuged at 15,493 $\times g$ for $15 \mathrm{~min}$. The supernatant was used for LC-MS analysis.

Two milliliters of urine sample were prepared using the same method as the plasma samples with a minor change. Rather than $300 \mu \mathrm{L}$ of acetonitrile and water $(50: 50, v / v)$, the residue was dissolved in $600 \mu \mathrm{L}$ of acetonitrile and water $(50: 50, v / v)$ and centrifuged at $15,493 \times g$ for $15 \mathrm{~min}$. The supernatant was collected for LC-MS analysis.

The feces sample was extracted with 15 times the amount of methanol-water (70:30, $v / v)$. The extract was centrifuged at $15,493 \times g$ for $15 \mathrm{~min}$. The supernatant was collected.

\subsection{Data Processing}

Data processing was carried out with Peakview (Version 2.0, AB SCIEX) and MetabolitePilot ${ }^{\mathrm{TM}}$ (Version 1.5, AB SCIEX). Possible biotransformations which include hydroxylation, demethylation, ketonization, glucuronidation, sulfate conjugation, and combinations were set to analyze metabolites using MetabolitePilot ${ }^{\mathrm{TM}}$ software by comparing the samples and the control.

\section{Conclusions}

In this study, the metabolic profile of skimmianine in rats was characterized based on ultra-performance liquid chromatography coupled with quadrupole time-of-flight tandem mass spectrometry. A total of 16 metabolites of skimmianine were identified tentatively in the rat plasma, urine, and feces after the oral administration of skimmianine. All of these metabolites are reported for the first time in this publication. The predominant metabolic pathways were an epoxidation of 2,3-olefinic on its furan ring and followed by the hydrolysis of its epoxide ring, O-demethylation, and subsequent glucuronidation or sulfation. The 2,3-olefinic on the furan ring, the methoxy group, and the $\mathrm{H}$ of the benzene ring were the metabolic reactive sites. The results are important for understanding the biotransformation processes of skimmianine and the related furoquinoline alkaloids and provide a basis for the further study of skimmianine.

Supplementary Materials: Supplementary materials are available online. Figure S1: Extracted ion chromatogram of skimmianine standard. Figure S2: Extracted ion chromatograms of skimmianine and its metabolites in rats: A, blank plasma sample; B, blank urine sample; C, blank feces sample. Figure S3: MS ${ }^{1}$ and $\mathrm{MS}^{2}$ spectra of parent drug and its metabolites identified in rat plasma sample. Figure S4: $\mathrm{MS}^{1}$ and $\mathrm{MS}^{2}$ spectra of parent drug and its metabolites identified in rat feces sample.

Acknowledgments: This work was financially supported by the grants (No. [2013]389) from the central government supports the development of special funds for local colleges and universities in China-Chinese materia medica (Guangdong finance and education).

Author Contributions: A.H., H.X. and W.C. designed the research; A.H., D.C., X.J. and C.L. performed the research; A.H., R.Z., J.L. and Y.C. analyzed the data; A.H. and H.X. wrote the paper.

Conflicts of Interest: The authors declare no conflict of interest.

\section{References}

1. Ratheesh, M.; Sindhu, G.; Helen, A. Anti-inflammatory effect of quinoline alkaloid skimmianine isolated from rutagraveolens 1. Inflamm. Res. 2013, 62, 367-376. [CrossRef] [PubMed]

2. Yang, Z.; Zhang, D.; Ren, J.; Yang, M. Skimmianine, a furoquinoline alkaloid from zanthoxylumnitidum as a potential acetylcholinesterase inhibitor. Med. Chem. Res. 2012, 21, 722-725. [CrossRef]

3. Chang, Z.Q.; Wang, S.L.; Hao, C.Y.; Liu, F.; Bian, C.F.; Chen, J.M. Analgesic, antispastic and sedative effects of skimmianine. Zhongguoyao li xuebao=Acta Pharmacol. Sin. 1982, 3, 163-165. 
4. Yoon, J.S.; Jeong, E.J.; Kim, Y.C.; Yang, H.; Kim, S.H.; Sung, S.H.; Kim, Y.C. Inhibitory alkaloids from dictamnusdasycarpus root barks on lipopolysaccharide-induced nitric oxide production in BV2 cells. J. Enzyme Inhib. Med. Chem. 2012, 27, 490-494. [CrossRef] [PubMed]

5. Chang, Z.Q.; Wang, S.L.; Liu, F.; Zhu, M.Y.; Tang, X.C. No physical dependence of skimmianine in mice, rats and monkeys. Zhongguoyao li xuebao=Acta Pharmacol. Sin. 1982, 3, 223-226.

6. Ye, Y.; Liu, J.; Liu, X.; Qiu, J.; Min, H.; Zheng, R.; Xu, H.; Li, H.; Zhan, R.; Chen, W. Antibacterial constituents from roots of zanthoxylumnitidum. Chin. Tradit. Herb. Drugs 2013, 44, 1546-1551.

7. Yang, G.H.; Chen, D.F. Alkaloids from the roots of zanthoxylumnitidum and their antiviral and antifungal effects. Chem. Biodivers. 2008, 5, 1718-1722. [CrossRef] [PubMed]

8. Chen, K.S.; Chang, Y.L.; Teng, C.M.; Chen, C.F.; Wu, Y.C. Furoquinolines with antiplatelet aggregation activity from leaves of melicopeconfusa. Planta Medica 2000, 66, 80-81. [CrossRef] [PubMed]

9. Cardoso-Lopes, E.M.; Maier, J.A.; da Silva, M.R.; Ragasini, L.O.; Simote, S.Y.; Lopes, N.P.; Pirani, J.R.; Bolzani, V.d.S.; Marx Young, M.C. Alkaloids from stems of Esenbeckia leiocarpa Engl. (Rutaceae) as potential treatment for alzheimer disease. Molecules 2010, 15, 9205-9213. [CrossRef] [PubMed]

10. Garcia-Argaez, A.N.; Apan, T.O.R.; Delgado, H.P.; Velazquez, G.; Martinez-Vazquez, M. Anti-inflammatory activity of coumarins from decatropis bicolor on tpa ear mice model. Planta Medica 2000, 66, $279-281$. [CrossRef] [PubMed]

11. Chen, J.-J.; Wang, T.-Y.; Hwang, T.-L. Neolignans, a coumarinolignan, lignan derivatives, and a chromene: Anti-inflammatory constituents from zanthoxylumavicennae. J. Nat. Prod. 2008, 71, 212-217. [CrossRef] [PubMed]

12. Jansen, O.; Akhmedjanova, V.; Angenot, L.; Balansard, G.; Chariot, A.; Ollivier, E.; Tits, M.; Frederich, M. Screening of 14 alkaloids isolated from haplophyllum a. Juss. For their cytotoxic properties. J. Ethnopharmacol. 2006, 105, 241-245. [CrossRef] [PubMed]

13. Varamini, P.; Javidnia, K.; Soltani, M.; Mehdipour, A.R.; Ghaderi, A. Cytotoxic activity and cell cycle analysis of quinoline alkaloids isolated from Haplophyllum canaliculatum Boiss. Planta Medica 2009, 75, 1509-1516. [CrossRef] [PubMed]

14. Yang, C.H.; Cheng, M.J.; Lee, S.J.; Yang, C.W.; Chang, H.S.; Chen, I.S. Secondary metabolites and cytotoxic activities from the stem bark of zanthoxylumnitidum. Chem. Biodivers. 2009, 6, 846-857. [CrossRef] [PubMed]

15. Byler, K.G.; Wang, C.; Setzer, W.N. Quinoline alkaloids as intercalative topoisomerase inhibitors. J. Mol. Model. 2009, 15, 1417-1426. [CrossRef] [PubMed]

16. Paulini, H.; Eilert, U.; Schimmer, O. Mutagenic compounds in an extract from Rutae Herba (Ruta graveolens L.). I. Mutagenicity is partially caused by furoquinoline alkaloids. Mutagenesis 1987, 2, 271-273. [CrossRef] [PubMed]

17. Henriques, J.A.; Moreno, P.R.; Von Poser, G.L.; Querol, C.C.; Henriques, A.T. Genotoxic effect of alkaloids. Mem. Inst. Oswaldo Cruz 1991, 86, 71-74. [CrossRef] [PubMed]

18. Ma, L.; Wang, Y.; Yang, X. Absorption of dictamnine and skimmianine across human intestinal epithelial in a model of caco 2 cell monolayers. Chin. J. New Drugs 2008, 17, 124-128.

19. Zhiqing, C. The measurement of skimmianine in rabbit's blood serum with uv spectrometric method. J. Henan Med. Coll. 1985, 20, 104-106.

20. Xie, C.; Zhong, D.F.; Yu, K.T.; Chen, X.Y. Recent advances in metabolite identification and quantitative bioanalysis by LC-Q-TOF MS. Bioanalysis 2012, 4, 937-959. [CrossRef] [PubMed]

21. Wang, P.; Zhao, Y.; Zhu, Y.; Sun, J.; Yerke, A.; Sang, S.; Yu, Z. Metabolism of dictamnine in liver microsomes from mouse, rat, dog, monkey, and human. J. Pharma. Biomed. Anal. 2016, 119, 166-174. [CrossRef] [PubMed]

22. Feng, P.; Hu, X.; Wu, X.; Dong, J.; Cai, X. Characterization of an epoxide-derived metabolite of dictamnine using high-performance liquid chromatography with hybrid linear trap quadrupole orbitrap mass spectrometry. J. Sep. Sci. 2016, 39, 4858-4865. [CrossRef] [PubMed]

23. Kilier, B.; Schimmer, O. Microsomal metabolism dictamnine: Identification of metabolites and evaluation of their mutagenicity in Salmonella typhimurium. Mutagenesis 1999, 14, 181-185. [CrossRef]

Sample Availability: Not Available.

(C) 2017 by the authors. Licensee MDPI, Basel, Switzerland. This article is an open access article distributed under the terms and conditions of the Creative Commons Attribution (CC BY) license (http:/ / creativecommons.org/licenses/by/4.0/). 